\title{
The impact of stock market manipulation on Nigeria's economic performance
}

\author{
Babatunde Akinmade ${ }^{1}$, Festus Fatai Adedoyin ${ }^{1}$ and Festus Victor Bekun ${ }^{2,3^{*}}$ (1)
}

\section{*Correspondence:}

fbekun@gelisim.edu.tr

${ }^{2}$ Department of Logistics

and Transportation, Istanbul

Gelisim University, Istanbul,

Turkey

Full list of author information

is available at the end of the

article

\begin{abstract}
This study is the first attempt to empirically analyse stock market manipulation on the Nigerian Stock Exchange and its consequences on economic performance. The empirical investigation employs a broad data set of 186 actual manipulation cases indicted by the Nigerian Security and Exchange Commission between 2002 and 2016. We embrace market microstructure analysis and the event study method to understand how various manipulation techniques impact on market measures, and the Error Correction Model to evaluate their economic effects. Manipulation is found to distort market efficiency measures (such as market capitalization, value traded ratio and All-Share Index) and genuine traders are forced to exit the market to avoid possible trading with a manipulator. Such huge divestment and the subsequent financial risk weaken the ability of the Stock Exchange market to improve economic performance, creating negative consequences at the post-manipulation period. Essentially, economic variables (such as the GDP) react negatively to manipulative trading. This finding is insightful and a prompt to the Securities and Exchange Commission to design policy responses towards deterring and prosecuting unfair trading practices or other activities that contravene the market rules.
\end{abstract}

Keywords: Nigerian Stock Exchange, Market manipulation, Market microstructure, Event study, Market efficiency measures, Market indicators, Economic growth

\section{Introduction}

A typical stock market is characterized by the trading of equity securities such as shares which represent ownership in a particular corporation (Cheng and Gul 2010). Big corporations often issue these securities with a promise of good returns in the form of dividends, subject to satisfactory performance of the issuing organization. Frank and Goyal (2007) argued that the present performance of a company or an expectation of good performance has a direct impact on the share price. It is also a common claim among researchers that the economic climate of corporations is one huge factor that causes fluctuations in investors' sentiment and ultimately induces share price behaviour. Every appreciation of share price is, therefore, an indication of potential gains for investors. When stock exchanges make decent trading facilities available to market participants, it facilitates smooth trading of listed equity securities (Gao and Kling 2006). Expectedly, a well-developed stock exchange increases savings by ensuring the availability of diverse

(c) The Author(s) 2020. This article is licensed under a Creative Commons Attribution 4.0 International License, which permits use, sharing adaptation, distribution and reproduction in any medium or format, as long as you give appropriate credit to the original author(s) and the source, provide a link to the Creative Commons licence, and indicate if changes were made. The images or other third party material in this article are included in the article's Creative Commons licence, unless indicated otherwise in a credit line to the material. If material is not included in the article's Creative Commons licence and your intended use is not permitted by statutory regulation or exceeds the permitted use, you will need to obtain permission directly from the copyright holder. To view a copy of this licence, visit http://creativeco mmons.org/licenses/by/4.0/. 
financial securities to savers (Boubakari and Jin 2010). By doing this, savers' portfolios are diversified, risks are effectively reduced, and capital is efficiently allocated to the most productive units of the economy.

Apart from general risks and governance indices (Asongu 2012, 2013; Asongu and Nwachukwu 2016; Kirikkaleli 2016, 2020), a notable problem preventing stock markets from playing this important role in enabling economic growth is the existence of stock market manipulation (Aggarwal and Wu 2003). Market manipulation has always been suspected to pose a serious threat to market efficiency and substantially curtail its ability to effectively act as an engine of growth (Gerace et al. 2014), although empirical evidence to support this concern in the emerging markets is still scarce in the literature. Moreover, very few empirical evidence is found focusing on well-developed countries. We should notice that most of these empirical studies (such as Gerace et al. 2014; Aggarwal and Wu 2003) considered only how manipulation impacts stock market quality or efficiency. In Nigeria, similar empirical studies (such as Nurudeen 2009; Alajekwu and Achugbu 2012; Onakoya 2013; Brown and Nyeche 2016) have also advanced to present the link between stock market efficiency and economic performance. Meanwhile, the aforementioned studies failed to present a model that considers hindrances to stock market efficiency in the case of Nigeria. This study is expected to address these issues. It is interesting to note that the impact of stock market manipulation on growth is not a direct one. By illustrating stock market manipulation as a hindrance to market efficiency and then investigating the negative influence of a distorted stock market on economic performance, this research combines two different variables in a single study.

The Nigeria Stock Exchange (NSE), which was established in 1961, offers a platform for trading of shares and other financial securities (Nurudeen 2009). Over the years, this important role of NSE has facilitated the process of mobilizing funds from the surplus to the deficit units of the economy. As a result of this, a good number of corporations have been able to improve productive capacity and increase investment, an enabling environment for economic growth. According to Nurudeen (2009), the Nigerian Capital market consists of the primary market, the secondary market, and the second-tier security market. The Investment and Securities Act (ISA) accredited the exchange with the Security and Exchange Commission (SEC) expending resources to regulate the market activities. Among the regulatory responsibilities of SEC are detection, investigation and prosecution of manipulation cases, unfair trading practices and other activities that contravene the market rules (Aliyu 2014). According to Alajekwu and Achugbu (2012), there are 180 listed companies on NSE, with the exchange maintaining sectoral indices based on market capitalization methodology and also adopting the All-Share Index as a gauge for overall market performance.

Over the years, the Nigerian stock market grew considerably both in size and liquidity. Until 2008, the stock market performance remained similar to that of many developed stock markets across the globe with the market indicators hitting a record high. For instance, market capitalization in 2007 (N13, 295 billion) had a quantum leap from its 1990 figure of N16.36 billion (Alajekwu and Achugbu 2012). Similarly, market turnover grew to roughly N2, 100 billion in 2007 from its 1990 figure of N0.31 billion (Brown and Nyeche 2016). The overall performance of the exchange, measured by the All-Share Index, was reported by Nurudeen (2009) to have climaxed the era of the stock market 
boom. The index peaked all-time high 57,990.2 points in 2007 from its low 1990 figure of 513.8 points. However, the impressive era of the stock market growth came to an end as a result of various sharp practices by the market participants. At the moment, the AllShare Index stands at 25, 339.39 points while the market capitalization is roughly N10, 160 billion (Brown and Nyeche 2016).

Although the Nigeria capital market might be considered as young, it is among the fastest-growing emerging financial market in recent years. Aliyu (2014) opined that, despite the market showing a lot of potentials, investigations reveal the existence of various unethical and harmful practices that contributed to its collapse in 2008. Sadly, the Nigerian Stock Exchange failed to score high on integrity and the market was negatively impacted resulting in huge divestment from the country, continuous loss of employment and a lot more loss in tax revenues. Aliyu's study revealed that some investors were, long before the global economic meltdown, worried by high valuations, insider trading, illegal sales of stocks by brokers, sales of non-existing shares to investors, diversion of returns on investors' stock by stockbrokers, pump and dump. We should know that, even without the global economic meltdown of 2008, the overly pumped Nigerian stocks were a product of huge spread abuse and market manipulation of unbelievable magnitude and was headed for a total collapse.

Consequently, this research aims to examine the level of Nigerian stock market efficiency at the post-manipulation period and its impact on economic performance. This aim focuses on answering the following questions: does market manipulation have a significant impact on Nigeria Stock Market efficiency; what is the trend in the relationship between stock market efficiency and economic growth in Nigeria?

This research is structured into five sections. Section 2 contains a review of the literature on the contribution of the stock market to economic growth. Sections 3 and 4 entail data and methods and discussion of results, respectively, while section 5 concludes the research with policy implications.

\section{Literature review}

Many attempts have been made by various scholars to examine the impacts of financial risks as well as stock market efficiency on economic growth (Batuo et al. 2018; Belcaid and El Ghini 2019; Boamah 2017; Kirikkaleli 2019; Kirikkaleli and Gokmenoglu 2019; Numapau 2018; Nyasha and Odhiambo 2017; Zhang et al. 2016). Bencivenga and Smith (1991) incorporated multiple assets into an endogenous growth model; the idea was to examine the reaction of economic growth indicators to every shift in financial intermediation levels. The authors asserted that an efficient stock market lessens socially unnecessary liquidation of capital, thereby creating a positive long-run effect on economic performance. In a similar vein, King and Levine (1993) supported the opinion that stock market is an engine of growth; their cross-country study empirically examined the degree of association between four indicators of financial development and GDP growth. King and Levine found that financial development significantly impacts on both the rate of capital accumulation and economic efficiency measures. The study of Levine and Zervos (1996) collected data on 41 countries between 1986 and 1993 to examine the different stock market indicators and how they impact on economic development; it was 
reported that stock market efficiency does not only influence economic growth, but also creates a basis to forecast the growth rates of per capita GDP.

Agarwal and Mohtadi (2004) reviewed 21 developing economies using a dynamic panel method over 21 years and reported a positive correlation between various stock market indicators (market capitalization ratio and shares traded ratio), and economic growth. Their results indicate that efficient stock markets improve private investment behaviour. Similarly, Gursoy and Muslumov (1999) found a two-way causal relationship between stock market efficiency and economic growth; their study of 20 countries involved time series data between 1981 and 1994, the authors used Sims' causality test based on Granger causality assumptions and pointed out a strong positive relationship between the stock market and economic growth in developing countries. Minier (2003) examined the relationship between financial development and growth using regression tree techniques; Minier's findings are more specific in that those countries with high market capitalization were found to show a significant positive relationship between financial development and economic growth. However, Minier (2003) reported a significant negative association for countries with low capitalization.

In Nigeria, Adamu and Sanni (2005) investigated the long-run relationship between the Nigeria Stock Market and economic growth using Granger Causality Test and regression analysis. The authors found a one-way relationship between market capitalization and GDP growth. Additionally, their study reflects a two-way causality between market turnover and GDP growth. In a similar vein, Anigbogu and Nduka (2014) investigated the long-run association of Nigeria stock market performance and economic growth using the Vector Error Correction Model. The authors reported that stock market efficiency causes GDP growth but with feedback effect.

However, Nyong (1997) examined the relationship between stock market efficiency and economic growth and revealed a negative relationship. Nyong's model adopted market indicators such as market capitalization-GDP ratio, the value of the transaction-GDP ratio, Listing and the degree of financial depth. The observation of Osinubi and Amaghionyeodiwe (2003) regarding the role of the Nigerian stock market on economic growth, between 1980 and 2000, did not support the assertion that stock market efficiency stimulates economic growth. The empirical study of Arzarmi et al. (2005) analysed the relationship between the stock market and economic growth in India and reported no evidence to argue that Indian stock market efficiency promotes economic growth during the period of their study. Although, they found evidence to corroborate the significance of stock market efficiency in economic development throughout the preliberalization era but discovered a negative association in the post-liberalization period.

By using ordinary least square (OLS) techniques, Alajekwu and Achugbu (2012) evaluated the role of Nigeria stock market efficiency on economic growth from 1994 to 2008. Their study adopted market capitalization as a proxy for stock market size and turnover ratio for market liquidity. Alajekwu and Achugbu found that market capitalization negatively correlates with economic growth while turnover ratio had a significant positive correlation with economic growth. The study of Onakoya (2013) examined the relative influence of stock market volatility on economic performance using Exponential Generalized Autoregressive Conditional Heteroscedasticity 
(EGARCH). Onakoya's study revealed that persistent volatility shock in the Nigerian Stock Exchange created a distortion between 1980 and 2010, and negatively impacted on economic growth.

While existing empirical studies (Cournède and Denk 2015; Madsen and Ang 2016; Asteriou and Spanos 2019) may have adopted distinct approaches and measures to illustrate stock market-growth nexus, there appears to be a consensus in two particular areas. First, unlawful market practices widen financial risks in the stock market, in terms of market volatility, declined capitalization and equity volatility (Zhang et al. 2016). Secondly, stock market risk tolerance capacity plays a positive role in furthering economic growth (Zhang et al. 2016). Needless to say, that, the prevalence of unfair trading practices undermines risk tolerance capacity especially if detection and prosecution policies are unresponsive (Wei 2014). In this vein, financial risks ultimately translate into economic risks. In effect, manipulation directly constitutes a financial risk and indirectly an economic risk, with a strong likelihood to impair economic performance during and after the manipulation period. Essentially, risk tolerance capacity mediates the ability of stock markets to trigger economic growth. It is not surprising, that well-developed markets (with robust risk tolerance capacity) achieve economic recovery rather quickly following economic crisis.

Given that stock market volatility is a good measure of stock market risk tolerance capacity, empirical studies (such as Lin and Huang 2012; Yeh et al. 2013; Huang et al. 2014) have prevalently examined the interaction between financial risk and economic growth by focusing on the volatility of financial structure. Huang et al. (2014), for instance, report the significant effect of financial development volatility on industrial growth instability. They found a positive association between the two variables. Similarly, the findings in Yeh et al. (2013) reveal that financial structure co-integrates with its volatility as well as economic growth. Rather than focusing on the financial structure volatility, Zhang et al. (2016) capture the effects of both the financial system and financial risk tolerance capacity on economic growth. The authors' panel unit root tests and co-integration analysis reveal a stable long-run association between financial risk tolerance capacity and economic growth. Also, using a two-step system Generalized Method of Moments (GMM), Zhang et al. (2016) find a negative effect of risk tolerance capacity on growth but a positive effect of the lagged risk tolerance capacity on growth. This finding is insightful and particularly suggests that a higher risk tolerance capacity energizes the economy to cushion economic risks. And this is a good pre-condition for growth.

Based on the empirical findings above, this research will examine the following hypothesis; stock market efficiency has no significant impact on economic growth in Nigeria between 2002 and 2016, and stock market efficiency has a significant impact on economic growth in Nigeria between 2002 and 2016. In summary, the findings from the literature reviewed reveal scanty empirical literature regarding the impact of market manipulation on stock market efficiency. Indeed, it is clear that the results of the few empirical studies focused on developed countries. Since manipulation has been noticed to impact on the market price in most cases, market microstructure theory is adopted to describe how certain trading mechanisms affect the market price behaviour. Similarly, there was a review of literature that suggests how much stock markets have assumed the role of engine of growth, thereby influencing economic performance. 


\section{Data and methodology}

The model of Aggarwal and Wu (2003) considered three simple cases of manipulation. In all the cases, the model identified four different periods. There is a time 0 when all shares are held or sold, a time 1 when share prices are manipulated, time 2 when stocks are bought or sold and time 3 when the true stock price is revealed. This research adopts the event study method to evidence: (a) whether manipulation distorts each market efficiency measure away from its original levels and (b) investigate the impact of manipulative trading on aggregate market indicators.

By using the event study method, this research examines a broad data set of 186 actual manipulation cases as prosecuted by the Security and Exchange Commission of Nigeria between 2002 and 2016. The manipulation sample cases majorly consist of collected data from the annual report of SEC. The intra-day data collected from the Nigeria Stock Exchange Database includes opening and closing prices, the daily average of high and low prices, volume of trade, and average ask and bid prices. It is important to understand how various manipulation activities impact on market measures, this research embraces market microstructure analysis, adopting bid-ask spread to indicate information asymmetry and as a good measure of market efficiency.

Furthermore, this research empirically tests market reactions to manipulation using 'event study'. Ball and Brown (1968) opined that event studies were first adopted as a tool to ascertain the relationship between market prices and company earnings. Over time, the US courts have supported the use of event study to observe the effect of market manipulation (Leas 1974). According to Fischel and Carlton (1982), event study is a robust econometric tool that could be used to determine whether manipulation activities distort share prices to a spuriously low or high level. The 'event' period in this study is represented by 150 days before and 150 days after the manipulation date.

The variables adopted (market efficiency measures) in this study are the bid-ask spread (BAS): This is the difference between the closing ask price and the closing bid price of stocks in the market. Aggarwal and Wu (2003) opined that BAS is a reliable gauge for quantifying information asymmetry and efficiency:

$$
\text { Bid }- \text { Ask Spread }=\text { Closing Ask price }- \text { Closing Bid price. }
$$

Volume: the number of shares that change hands during a particular day

Proportional bid-ask spread (PBAS): the PBAS relevantly controls for stock prices' fluctuations over a variety of stocks and time:

$$
\text { ProportionalBid }- \text { AskSpread }=\frac{\text { ask price }- \text { bid price }}{(\text { ask price }+ \text { bid price }) / 2} .
$$

Volatility: it indicates the amount of uncertainty regarding the variations in stocks' value. It is a measure of risk, estimated for each stock as the logarithm of the daily proportion of high and low stock prices:

$$
\text { Volatility/Risk }=\log \left[\frac{\text { High }}{\text { Low }}\right] .
$$


Dichotomous variable (DV): this is a variable that contains exactly two separate values. For clarity, this variable assumes a pre-event value of 0 and a post-event value of 1 :

$\mathrm{DV}=0$, if observation occurs at pre - event period and $D=1$ if otherwise.

In determining the impacts of manipulation on stock market efficiency, this study identifies a period around the manipulation event. A period of 300 days around the event is adopted, examining the market efficiency measures over 150 days before the manipulation period and 150 days after. For easy comparison of the variables' reactions to manipulation, cross-sectional averages were estimated for each day. The averages reliably indicate the market's buying and selling interests. It is therefore imperative to establish the impact of manipulation on the market by finding patterns in each variable, Univariate analysis is adopted as a tool to compare the market's state before and after manipulation. The significance of each variable is tested against the control period using $\mathrm{t}$-statistic. As a rule of thumb, $\mathrm{t}$-statistic is considered large if it exceeds 2 . If that happens, it is an indication that manipulation has a significant impact on the observed value. By combining univariate and regression analysis, this study presents a robust method to establish how stock market efficiency measures react to manipulation. Having selected BAS as a measure of efficiency, the impact of volume and volatility on BAS will be examined by running the set of regression below:

\subsection{First set regression}

$$
\begin{aligned}
& \mathrm{BAS}=\alpha_{0}+\alpha_{1} D t+\varepsilon t, \\
& \mathrm{PBAS}=\alpha_{0}+\alpha_{1} D t+\varepsilon t, \\
& \mathrm{BAS}=\alpha_{0}+\alpha_{1} D t+\alpha_{2} \text { Volume }+\alpha_{3} \text { Volatility }+\varepsilon t, \\
& \mathrm{PBAS}=\alpha_{0}+\alpha_{1} D t+\alpha_{2} \text { Volume }+\alpha_{3} \text { Volatility }+\varepsilon t .
\end{aligned}
$$

The statistical significance of volume and volatility on the measure of market efficiency (BAS and PBAS) is tested by the regression equations above. The coefficient of the independent variables is represented by $\alpha_{1}, \alpha_{2}$ and $\alpha_{3}$ and $\varepsilon$ is the error term.

In Eqs. 5 and 6 above, bid-ask spread and proportional bid-ask spread are regressed on the indicator variable (dichotomous variable). The use of an indicator variable as the independent variable exclusively reveals the degree at which bid-ask spread and proportional bid-ask spread are influenced by manipulation. It is imperative to mention that the proportional bid-ask spread adequately measures the relative spread and thus has a greater accuracy and precision potentials to reflect the relative variance between bids and asks as against the absolute spread shown in BAS. In Eqs. 7 and 8 above, BAS and PBAS are regressed on volume and volatility. The idea is to establish the extent to which spread is impacted by variability in volume and volatility.

It typifies a valid deduction to opine that the standard proxy for information asymmetry is the BAS. In a market situation where an average investor is willing to pay less than 
what a trader is asking to sell for, it must be that both the trader and the potential investor possess divergent information. Interestingly, the spread is sure not the only proxy for market efficiency. Easley and O'Hara (1987) asserted that there is both price (spread) and quantity (volume) dimension to market liquidity. The second set regression below examines what happens when the market volume is regressed on spread and volatility.

\subsection{Second set regression}

$$
\begin{aligned}
& \text { Volume }=0+\alpha 1 D t+\varepsilon t, \\
& \text { Volume }=\alpha 0+\alpha 1 D t+\alpha 2 \text { BAS }+\alpha 3 \text { Volatility }+\varepsilon t, \\
& \text { Volume }=\alpha 0+\alpha 1 D t+\alpha 2 \text { PBAS }+\alpha 3 \text { Volatility }+\varepsilon t .
\end{aligned}
$$

The statistical significance of the two sets of regression will be examined using the $p$ value approach. The p-value is the probability of obtaining a result not less than what was observed. With the null hypothesis in this study being that manipulation does not distort the market, the variable is considered to be statistically significant if the $p$-value takes a value less than the level of significance $(1 \%, 5 \%$ or $10 \%)$. In this case, there is strong evidence to reject the null hypothesis. Due to the existence of a high correlation between risk and returns, this study excludes returns, as an explanatory variable in the regression, to avoid multicollinearity in the results.

\subsection{Univariate analysis}

The adoption of univariate analysis is crucial to examine whether manipulation has a noticeable effect on the spread, market volatility, market prices and volume. For a decent analysis, the descriptive statistics of the pre-event period would be compared with that of the post-event period.

\subsection{The Nigerian stock market and economic growth}

This study examines the quantitative impact of the Nigerian stock market efficiency on economic growth using Error Correction Model between 2002 and 2016. Error Correction Models are theoretically driven approach particularly suitable to evaluate both short-run and long-run effects of time series data. As a result of the long-run stochastic trend of time series data, using this approach has proven to be insightful in recent years, especially in developing countries. This study closely follows the model of Choong et al. (2003) with slight modifications, their study conditioned stock market development on size and liquidity. To quantify the market size, Choong et al. (2003) used the ratio of market capitalization to GDP (capGDP); similarly, market liquidity was proxied by the ratio of market turnover to GDP (turGDP) in their study.

It has commonly been assumed that there are variables that impact on economic growth other than stock market efficiency measures. It is therefore imperative to take account of certain control variables, such as discount rate and trade openness, to avoid endogeneity problem (Gujarati 1995). Martin (2013) opined that government policy could shape the association between the stock market and economic 
growth. Through the central bank, required reserve ratio, discount rate or open market operation can be used to regulate the liquidity level in the equity market. By adopting discount rate as a control variable in this study, it is once again emphasized that an increase in the discount rate has the potential of reducing market liquidity level thereby causing a gradual decrease in the pace of economic activities. In like manner, the inclusion of trade openness (proxied by the ratio of trade to GDP) stresses the role of trade liberalization in allowing foreign entrants to tap the domestic stock market, thereby impacting on the aggregated growth of the economy. This study slightly modifies the original model by swapping value traded for market turnover as either variable provides a good measure for market liquidity. There is also an inclusion of the All-Share Index in the new model to indicate the changing value of share prices of all the listed companies on the Nigerian Stock exchange. Therefore, the econometric model for this study is expressed as:

$$
\mathrm{GDP}=f(\text { capR, vtR, ASI, toR, drR). }
$$

The above equation is linearized by expressing all the variables in logarithms form. This becomes necessary as a way of ensuring the regression model is appropriately analysed such that the variables are integrated into the same order. The linearized model is stated below:

$$
\lg (\mathrm{GDP})=\alpha 0+\alpha 1 \lg (\mathrm{capR})+\alpha 2 \lg (\mathrm{vtR})+\alpha 3 \lg (\mathrm{ASI})+\alpha 4 \lg (\mathrm{toR})+\alpha 5 \lg (\mathrm{drR})+\mathrm{U},
$$

where lg is logarithm; GDP, Gross Domestic Product; capR, market capitalization-GDP ratio; vtR, value traded-GDP ratio; ASI, All-Share Index; toR, openness of the economy; $\mathrm{drR}$, discount rate; $\mathrm{U}$, error/residual term; $\alpha 0$, the average estimated value of GDP (intercept) when capR, vtR, and ASI are Zero; $\alpha 1$, the estimated change in the average value of GDP for every unit change in market capitalization; $\alpha 2$, the estimated change in the average value of GDP for every unit change in value traded; $\alpha 3$, the estimated change in the average value of GDP for every unit change in All-Share Index; $\alpha 4$, the estimated change in the average value of GDP for every unit change in trade openness; and $\alpha 5$ is the estimated change in the average value of GDP for every change in discount rate. Also, the logarithmic form of all the variables becomes essential as log transformation causes linearity in parameters. Besides that this satisfies one of the ordinary least square assumptions, it also interprets regression coefficients more straightforward. The E-views 9.5 software is used in this study to analyse the data.

There are three basic explanatory variables in the research model; market capitalization ratio which is estimated as the ratio of market capitalization to GDP. This ratio reliably measures the market size per time; value traded ratio is a ratio provides a good measure for market liquidity. It is estimated as total traded value divided by GDP; All-Share Index which is a capitalization-weighted index that tracks the overall market behaviour of all listed equities on the market. The dependent variable is real Gross Domestic Product which is an inflation-adjusted measure is adopted in this research to indicate the level of economic performance per time. We also conduct Granger Causality Test; Unit Root Test; Co-integration Test; and estimate the Error Correction Model (ECM). 


\subsection{Summary of descriptive statistics}

It is imperative to present a statistical description of the data used in this study without necessarily drawing inference or extrapolation. The descriptive statistics for dependent (GDP) and independent variables (market capitalization ratio, value traded ratio, AllShare Index, trade openness, and discount rate) are stated in Table 1.

There is a significant range between the minimum and maximum figures of the stock market indicators. This range is not surprising, as the Nigerian stock market witnessed a considerable level of volatility as evidenced earlier in this study. Also remarkable are the Jarque-Bera values of the All-Share Index, discount rate and value traded ratio. JarqueBera is an important estimate to ascertain whether the series is normally distributed. With the null hypothesis being that the series is normally distributed as against the alternative hypothesis that the series is not normally distributed. The Jarque-Bera statistic rejects the null hypothesis for value traded ratio ( $p$ value $=0.000008)$, All-Share Index $(p$ value $=0.006773)$ and discount rate ( $p$ value $=0.000000)$ as the probability values are less than 0.05 . This typifies the variables are not normally distributed. However, the JarqueBera statistic accepts the null hypothesis of a normal distribution for GDP, market capitalization ratio and trade openness. Similarly, kurtosis of the variables which suggests normality of probability distribution is found to be platykurtic for market capitalization ratio and GDP (i.e. $>3$ and fatter tails), leptokurtic for value traded ratio, All-Share Index and discount rate (i.e. $<3$ with thinner tails), and approximately mesokurtic (i.e. equal to 3 and normally distributed).

\section{Results and discussion}

\subsection{Stock market manipulation and market efficiency: empirical univariate results}

The estimated time series for each variable, bid-ask spread, proportional bid-ask spread, risk, returns and volume (market efficiency measures) for 150 days before and after the event date are shown in Table 2.

The results above show that manipulation noticeably impacts on all the adopted variables. For instance, comparing the market variables at the manipulation date with the average market variables reveals a striking variance. As stated earlier that BAS is a

Table 1 Descriptive statistics

\begin{tabular}{lllllll}
\hline & GDP & CAPR & VTR & ASI & TOR & DRR \\
\hline Mean & 89.89133 & 0.115798 & 0.021606 & 28640.51 & 0.069264 & 17.84450 \\
Median & 80.33500 & 0.116217 & 0.011457 & 25729.36 & 0.063728 & 17.07000 \\
Maximum & 160.1300 & 0.255886 & 0.086470 & 62606.90 & 0.142032 & 26.25000 \\
Minimum & 35.61000 & 0.022091 & 0.000596 & 10963.11 & 0.020778 & 13.86000 \\
Std. Dev. & 36.41443 & 0.059681 & 0.023491 & 11728.22 & 0.026683 & 2.346689 \\
Skewness & 0.127628 & 0.111297 & 1.465215 & 0.940792 & 0.562182 & 1.950777 \\
Kurtosis & 1.663071 & 2.250675 & 3.881980 & 3.674939 & 2.902756 & 6.998026 \\
Jarque-Bera & 4.630420 & 1.527589 & 23.41327 & 9.989744 & 3.184130 & 78.01585 \\
Probability & 0.098745 & 0.465895 & 0.000008 & 0.006773 & 0.203505 & 0.000000 \\
Sum & 5393.480 & 6.947884 & 1.296340 & 1718431 & 4.155822 & 1070.670 \\
Sum Sq. Dev. & 78234.65 & 0.210147 & 0.032559 & $8.12 \mathrm{E}+09$ & 0.042006 & 324.9101 \\
Observations & 60 & 60 & 60 & 60 & 60 & 60 \\
\hline Source Author's E-vina
\end{tabular}

Source: Author's E-view 9.5 Compilation 
Table 2 Cross-sectional average sample

\begin{tabular}{lclllr}
\hline Comparative date & Returns & Risk & BAS & PBAS & \multicolumn{1}{l}{ Volume } \\
\hline-1150 & -10.00788 & 0.033635 & 0.01410 & 0.07612 & $7,833,300,000$ \\
-1149 & -10.02241 & 0.028769 & 0.02867 & 0.08936 & $16,003,330,000$ \\
-1148 & -10.02113 & 0.030274 & 0.01557 & 0.09776 & $8,996,667,000$ \\
-12 & 0.000312 & 0.101815 & 0.023961 & 0.117616 & $8,846,667,000$ \\
-11 & -10.02025 & 0.080413 & 0.034102 & 0.182066 & $9,203,333,000$ \\
0 & 0.008368 & 0.101478 & 0.053288 & 0.31276 & $5,806,667,000$ \\
1 & -10.01729 & 0.048012 & 0.062061 & 0.163406 & $6,920,000,000$ \\
2 & 0.008895 & 0.074328 & 0.046018 & 0.130143 & $5,113,333,000$ \\
147 & 0.007271 & 0.042625 & 0.024768 & 0.187361 & $37,503,330,000$ \\
148 & 0.023982 & 0.079494 & 0.022015 & 0.127826 & $7,276,667,000$ \\
149 & 0.000883 & 0.031289 & 0.018643 & 0.11678 & $8,836,667,000$ \\
150 & -10.00048 & 0.041164 & 0.036353 & 0.126171 & $9,013,333,000$ \\
\hline
\end{tabular}

Source: Author's Brodgar 2.7.5 Compilation

Italic values indicates coefficients are significant at the $10 \%, 5 \%$ and $1 \%$ levels, respectively

Table 3 Statistical mean for a 300-day event period

\begin{tabular}{llllll}
\hline & PBAS & BAS & Returns & Risk & \multicolumn{1}{l}{ Volume } \\
\hline Pre-event mean & 0.1216 & 0.0237 & -10.0008 & 0.0434 & $10,944,432,333$ \\
Post-event mean & 0.1436 & 0.0239 & -10.0006 & 0.0480 & $15,657,499,250$ \\
Total mean & 1.1326 & 0.0238 & -10.0007 & 0.0457 & $13,300,965,791$ \\
Event & 0.3128 & 0.05329 & 0.008368 & 0.10147 & $5,806,667,000$ \\
\hline
\end{tabular}

Source: Author's Brodgar 2.7.5 Compilation

measure of market efficiency, it is worthy of note that when BAS widens it is an indication of huge information asymmetry in the market. As opined by Gerace et al. (2014) and Aggarwal and Wu (2003), manipulation widens BAS and compels traders to trade at distorted levels. Also, in Table 2, stock volume declined sharply as genuine traders are forced out of the market to avoid further loss of funds that could arise when they ignorantly trade with a manipulator. We should note that there has been a huge divestment from the Nigeria stock market in recent years, this might be resulting from investors' victimization by manipulators. Similar to the findings of Gerace et al. (2014) and Aggarwal and Wu (2003), market risk or volatility increased during the manipulation period. Expectedly, genuine traders would reasonably avoid trading when there is increased volatility. This once again explains why trade volume dwindled at the manipulation period. The descriptive means for the manipulated stocks are reported in Table 3. The event date written in bold font is the exact day manipulation.

Table 3 shows that all the market efficiency measures except volume are higher at the event date. The significant broadening of both the bid-ask spread and the proportional bid-ask spread is an indication of information leakage as market players begin to exercise fear of transacting with an assumed manipulator. The market participants begin to necessitate better compensation to cover for possible loss that may arise while trading with a suspected manipulator. For instance, Apati (2012) opined that the Nigerian banking sector stocks were the main target of manipulation in 2008, in his study he 
concluded that prices of banking stocks were driven up by $167 \%$ relative to other sectors. Little wonder Nurudeen (2009) argued that the Nigerian stock market collapsed as a result of the prices of banks stocks that collapsed at the post-manipulation period. The results in Table 3 present strong evidence to suggest that by unduly increasing the cost of a transaction, manipulation exacts a harmful effect on market efficiency.

The negative pre-event, post-event and total returns validate the evidence that the event period exhibited a negative growth. Despite this, there is a noticeable increase in both returns and prices on the event date. For instance, returns are found to have increased by a significant $141 \%$ than the day before, $110 \%$ increase on the pre-event mean and $108 \%$ on the total mean value (as shown in Table 2). This means that even in the face of eroded market integrity, manipulators were still able to push up stock prices to distorted levels. Quite interesting is the trend of the trading volume on the date of actual manipulation. It is discovered that the trading volume falls significantly below the total average. This finding once again corroborates the findings of Thel (1993), Aggarwal and $\mathrm{Wu}$ (2003) that there is a higher probability of thriving manipulation in a low liquidity market and the harmful impact of manipulative trading on stock prices expectedly impact on volume as a result of that.

\subsubsection{Market efficiency measures at pre- and post-manipulation period}

It is imperative to compare the descriptive statistics of the pre-event and post-event period to adequately understand how much the market measures are impacted by manipulation. We should note that manipulation impacts the market beyond the 'event' date and extend to the following 150 days during which the market tries to adjust to the existence of manipulation. The descriptive statistics for the pre- and post-event periods are shown in Table 4.

The table below illustrates the descriptive statistics for the manipulated stocks. The kurtosis, skewness, standard deviation, minimum, maximum median and mean of each adopted variable (BAS, PBAS, Return, Volatility and Volume) are reported in the table.

In Table 4, the enduring impact of manipulation is noticed to increase averages for the adopted variables. For instance, the mean for BAS increased by $51.5 \%$ in the post-event period. It is also seen that there was a noticeable widening of the median, minimum and maximum. The $10.5 \%$ increase in average market volatility reveals market reactions to the existence of manipulation. It should be noted that the kurtosis figure of both volatility and volume at the post-event period are noticeably leptokurtic; a sharp departure from normality. Figure 1 also illustrates the behaviour of bid-ask spread during the event period.

Illustrated in the figure is the bid-ask spread of the manipulated stocks on the Nigerian Stock Exchange from 2002 to 2016. The manipulation date is depicted as Day 0 in Fig. 3.

In Fig. 1, there are strikingly two spikes around Day 0 . The sharp expansion of the average bid-ask spread reflects a renewed concern and logically indicates the reactions of market participants regarding the possibility of transacting with a manipulator. It is particularly interesting to note that the noticeable spikes may indicate a typical information-based manipulation described as "rumourtage". This suggests that manipulators are propagating false information to influence market reactions up to a point where prices 


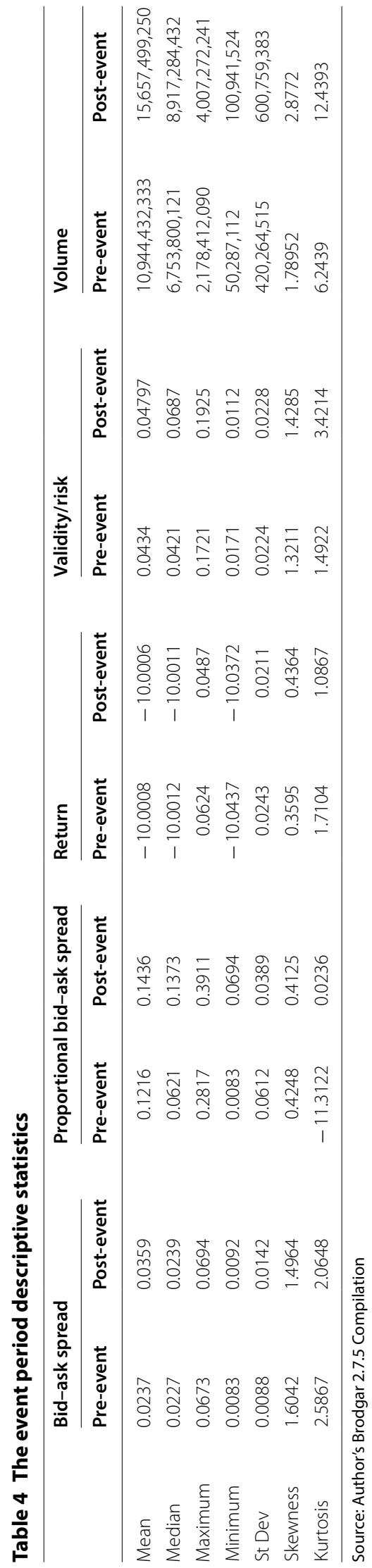




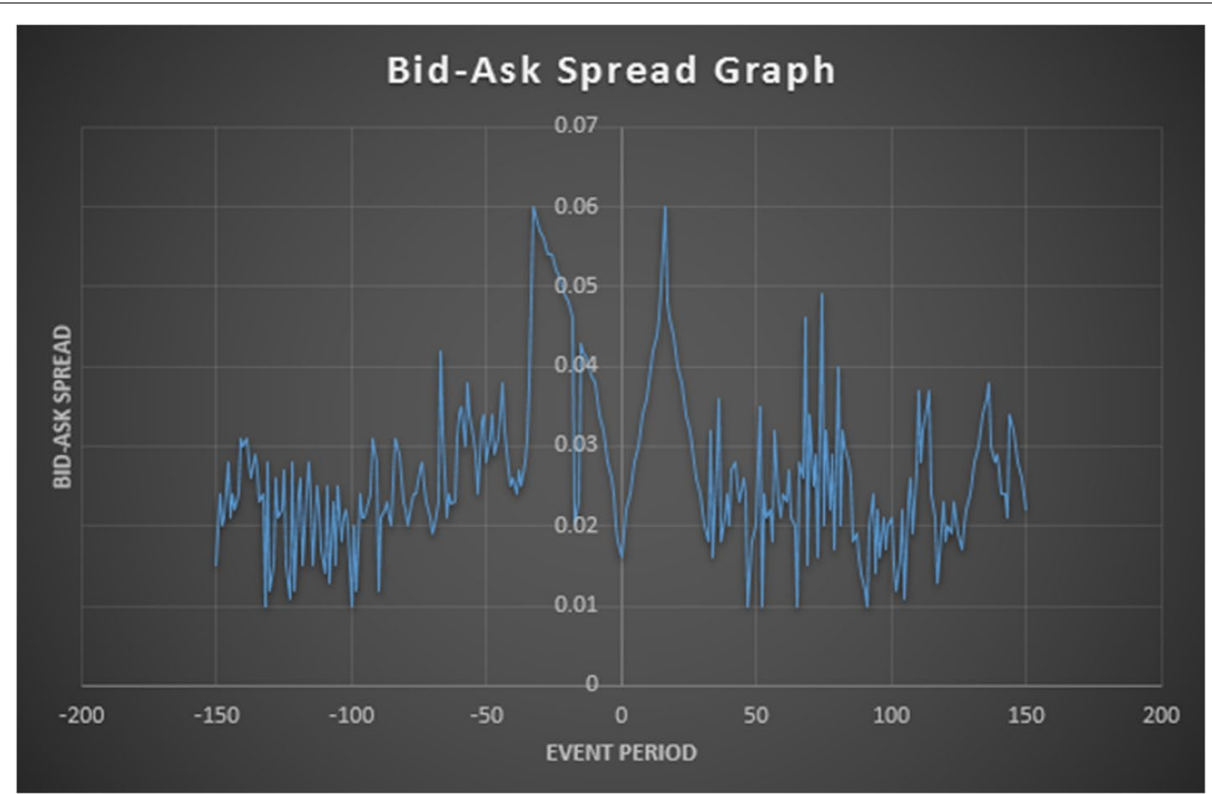

Fig. 1 Average bid-ask spread chart. Source: Author's Microsoft Excel Chart Compilation

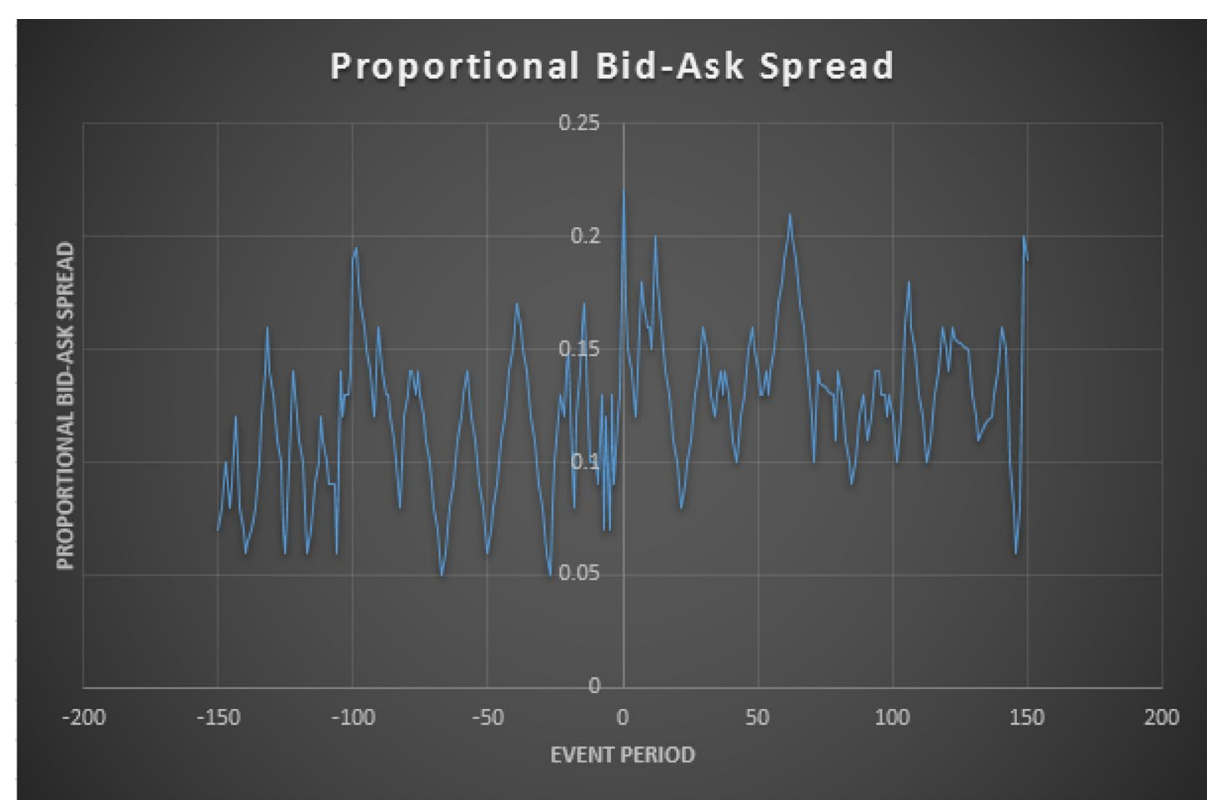

Fig. 2 Average proportional bid-ask spread chart. Source: Author's Microsoft Excel Chart Compilation

exceed the fair value of stocks. As Onakoya (2013) reported a great level of deficiency and corruption that permeated the Nigerian stock market such that both executive and council members of NSE were found to team up with stockbrokers to release false information. The following contraction and re-broadening of the bid-ask spread is a demonstration of deceptive acts by the manipulators carried out to prompt market participants to respond too quickly to benefit (in form of profit) from eventual adjustments see (Figs. 2, 3) for more insights. 


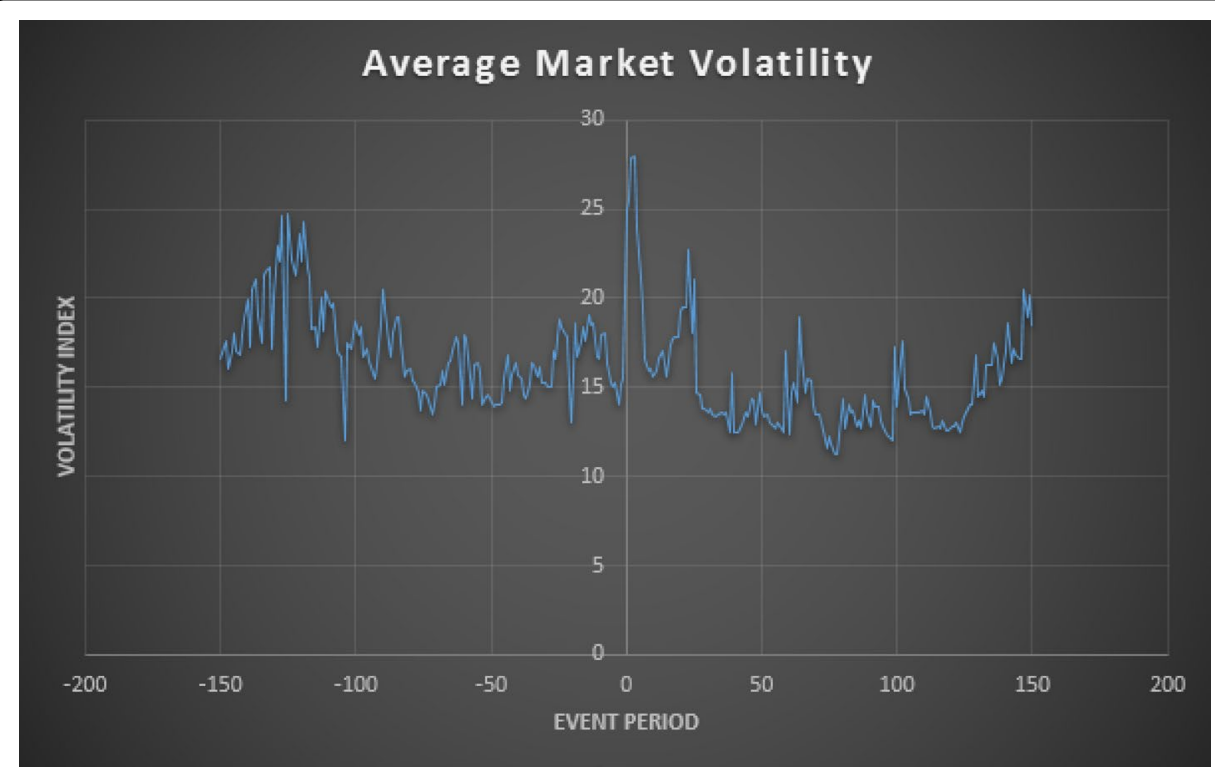

Fig. 3 Average market volatility. Source: Author's Microsoft Excel Chart Compilation

The figure shows the trend of proportional bid-ask spread resulting from the existence of manipulation on the Nigerian Stock Exchange from 2002 to 2016. The manipulation date is depicted as Day 0.

In Table 3, the post-manipulation period proportional bid-ask spread widens by more than $17.5 \%$. A conspicuous feature of the proportional bid-ask spread chart is how much it spikes at the manipulation date. As noted in Chapter 3, proportional bid-ask spread tends to suggest a more precise outcome of the relative difference in bids and asks. This conspicuous spike indicates a high level of information asymmetry, suggesting that NSE is not only inefficient at the post-manipulation period but also the manipulation date 0 .

This figure illustrates the average market risk/volatility resulting from manipulation on the Nigerian Stock exchange from 2002 to 2016.

In Fig. 4 , it is observed that manipulation is associated with widened volatility at the manipulation date. However, it is observed to be slightly lower in the post-manipulation period. Interestingly, this could be attributable to the policy measure by the Nigerian Stock Exchange to place a $10 \%$ limit on share price movement. The idea is that whenever stock prices increase or decrease beyond a particular threshold, it is adjudged to have got into the circuit. This particularly was a good response to ensure stock prices are not swayed uncontrollably to one direction. It is worthy of note however that, while this initiative to present a "circuit breaker" yielded a momentary result, manipulators still devised several strategic manipulative trading to avoid being trapped in the circuit. This may suggest the reason behind the short-range but highly irregular wave at the post-manipulation period.

\subsection{Analysis of multivariate regression results}

\subsubsection{Analysis of first set regressions}

The results of the earlier stated sets of regression (in chapter 3) are significant. For instance, the first sets of regression statistically examine the association between the 


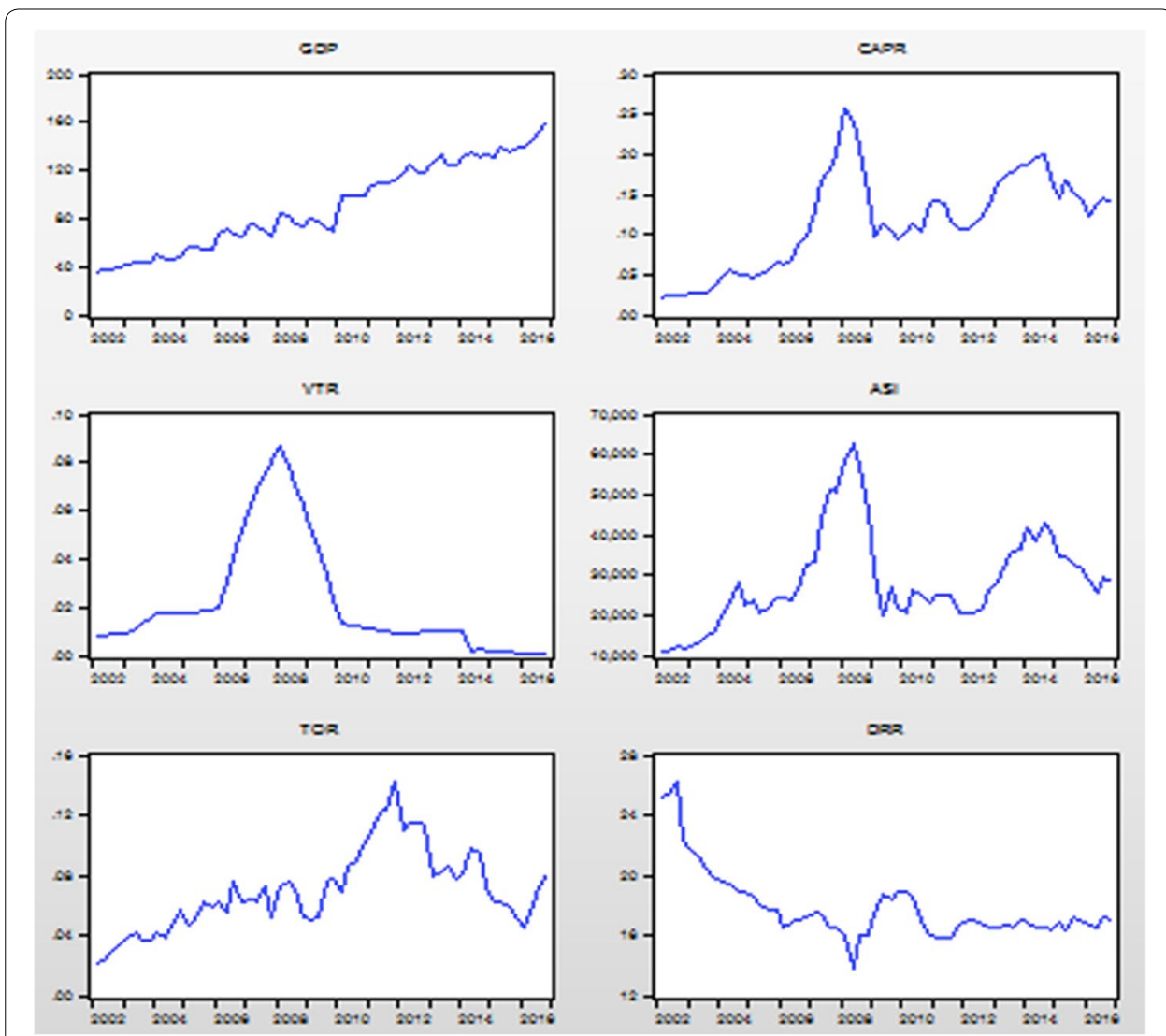

Fig. 4 Trend of aggregate market indicators from 2002 to 2016. Source: Author's E-views 9.5 Compilation

dichotomous variable (indicated as "change" in Table 5), volatility and volume on both bid-ask spread and proportional bid-ask spread. Table 5 shows the results of multivariate regression analysis for the first and second sets of regression (Eqs. 5 to 11) stated in Chapter 3 . The $10 \%, 5 \%$ and $1 \%$ level of significance are, respectively, denoted as *, ***;*** in table.

In Eq. 5, bid-ask spread is regressed on the dichotomous variable (denoted by a change in post-event mean). This becomes necessary to isolate the impact of manipulation on the bid-ask spread. The coefficient of the dichotomous variable (0.0002) is noted to be positive, this suggests strong evidence that bid-ask spread widens with manipulation. However, the result is not significant at $10 \%$ level of significance. Despite the insignificant positive relationship between manipulation and BAS in Eq. 5, Eq. 6 reveals a noticeable significant result at a $1 \%$ level of significance when the proportional bid-ask spread is regressed on the dichotomous variable. The proportional bid-ask spread greatly widens with manipulation at a $99 \%$ confidence level. This is an insightful finding especially by isolating the impact of manipulation on the proportional bid-ask spread.

It is interesting to find that the stated coefficient of volatility in the regression Eq. 7 is positive (0.08204). It is an indication that there exists a positive association between volatility and bid-ask spread. For instance, for every $1 \%$ increase in volatility, BAS is increased by $8.204 \%$. This result is informative. As noted earlier in this study that there exists an inverse relationship between BAS and market efficiency. Having evidenced 
Table 5 The event period's regression results

\begin{tabular}{|c|c|c|c|c|c|c|}
\hline & Intercept & Change & Volume & Volatility & Bid-ask spread & $\begin{array}{l}\text { Prop. bid-ask } \\
\text { spread }\end{array}$ \\
\hline \multicolumn{7}{|c|}{ First set regressions } \\
\hline \multicolumn{7}{|l|}{$\begin{array}{l}\text { Bid-ask } \\
\text { spread (on } \\
\text { dummy) }\end{array}$} \\
\hline Equation 5 & 0.0237 & 0.0002 & & & & \\
\hline$P$-value & $<0.0001^{* * *}$ & 0.31342 & & & & \\
\hline \multicolumn{7}{|l|}{$\begin{array}{l}\text { Prop. } \\
\text { bid-ask } \\
\text { spread (on } \\
\text { dummy) }\end{array}$} \\
\hline Equation 6 & 0.1216 & 0.0224 & & & & \\
\hline$P$-value & $<0.0001^{* * *}$ & $<0.0001^{* * *}$ & & & & \\
\hline \multicolumn{7}{|l|}{$\begin{array}{l}\text { Bid-ask } \\
\text { spread }\end{array}$} \\
\hline Equation 7 & 0.02013 & 0.00142 & -10.00003 & 0.08204 & & \\
\hline$P$-value & $<0.0001^{* *}$ & 0.38136 & $0.00212^{* * *}$ & $0.01511^{* *}$ & & \\
\hline \multicolumn{7}{|l|}{$\begin{array}{l}\text { Prop. bid-- } \\
\text { ask spread }\end{array}$} \\
\hline Equation 8 & 0.13181 & 0.02418 & -10.00005 & 0.43261 & & \\
\hline$P$-value & $<0.0001^{* * *}$ & $<0.0001^{* * *}$ & $0.06241^{*}$ & $<0.0001^{* * *}$ & & \\
\hline \multicolumn{7}{|c|}{ Second set regressions } \\
\hline \multicolumn{7}{|l|}{$\begin{array}{l}\text { Volume (on } \\
\text { dummy) }\end{array}$} \\
\hline Equation 9 & $10,944,432,333$ & $4,713,066,917$ & & & & \\
\hline$P$-value & $<0.0001^{* * *}$ & 0.8903 & & & & \\
\hline \multicolumn{7}{|l|}{ Volume } \\
\hline Equation 10 & $17,246,135,386$ & $6,605,310,181$ & & $-110,268,238,066$ & $-121,526,181,954$ & \\
\hline$P$-value & $<0.0001^{* * *}$ & 0.6219 & & $0.0924^{*}$ & $0.0033^{* * *}$ & \\
\hline \multicolumn{7}{|l|}{ Volume } \\
\hline Equation 11 & $16,873,273,330$ & $7,035,147,112$ & & $-110,487,638,057$ & & $-18,065,758,918$ \\
\hline$P$-value & $<0.0001^{* * *}$ & 0.3642 & & $0.0882^{*}$ & & $0.0647^{*}$ \\
\hline
\end{tabular}

Source: Author's Brodgar 2.7.5 Compilation

that manipulation widens volatility, volatility, in turn, relates to BAS by over $8 \%$. We can deduce that manipulation harms market efficiency. It is worthy of note however that, the volume coefficient is a small negative figure $(-0.00003)$ as shown in Table 5 . The negative coefficient of volume reveals an inverse association between total amount traded and spread. The results of both volatility and volume are noticeably significant at $5 \%$ and $1 \%$ level of significance, respectively. However, the dichotomous variable does not show a significant relationship with the spread.

In Eq. 8, there is a strikingly significant result. For instance, at a 1\% level of significance, both volatility and the dichotomous variable are statistically significant. Meanwhile, the volume is significant at $10 \%$ level of significance. The result of regression Eqs. 8 provides good evidence to suggest that manipulation widens relative spreads, triggers volatility, and causes a contraction of the trading volume. The higher explanatory power of the proportional bid-ask spread over bid-ask spread is clearly emphasized by the first set of regressions (Eq. 5 to 8). The findings that manipulation widens relative spread confirm the suggestion of Krinsky and Lee (1996) that there is an inherent informational risk in 
spreads such that transaction costs are often noticed to increase, liquidity reduced, and efficiency impaired with manipulation.

\subsubsection{Analysis of second set regressions}

In the second regression Eqs. 9 to 11, the volume is regressed on the dichotomous variable, bid-ask spread volatility and proportional bid-ask spread. The large coefficient figures are an indication of relatively huge data of trading volume in sharp contrast to that of the explanatory variables. In Eq. 9 where volume is regressed on the dichotomous variable, the $0.8903 p$ value indicates statistical insignificance of manipulation with trading volume. Similarly, Eqs. 10 and 11 reveal that the explanatory dichotomous variables are also not significant.

However, it is found in the second set of regressions that there exists a statistically significant association between spreads and, volatility and volume, although not between volume and the dichotomous variable. In both Eqs. 10 and 11, the coefficients of volatility are negative, this suggests that in a situation where stocks are highly volatile, market participants naturally avoid trading resulting in a declining trading volume. For instance, in Eq. 10, volume contracts by 10,268,238,066 (in Naira) for every $1 \%$ increase in volatility. At a $10 \%$ level of significance, volatility is found to be significant. It is particularly interesting to find that both bid-ask spread and proportional bid-ask spread have negative coefficients, an indication that when spreads widen as a result of manipulation, trading volumes dwindle. For instance, volume contacts by 21,526,181,954 (in Naira) for every $1 \%$ increase in BAS and 8,065,758,918 for every $1 \%$ increase in PBAS. This is an indication that trading volume is greatly impacted negatively as a result of manipulation. The statistical associations between volume and the bid-ask spread, volume and proportional bid-ask spread are strongly significant at $1 \%$ and $10 \%$ level of significance, respectively. This finding presents a renewed worry that manipulation is not only possible when trading volume is low but also when it is high.

Based on the above findings, the constructed null hypothesis that there is no significant relationship between stock manipulation and Nigerian market efficiency is rejected. Therefore, there exists strong evidence to conclude that the existence of manipulation on NSE worsened the market efficiency measures, distorted the aggregate market indicators, and made the market inefficient.

\subsection{The Nigeria stock market and economic growth: empirical investigation}

According to Gerace et al. (2014), there exists a direct positive relationship between trading volume and Market capitalization, volume and total value traded, volume and All-Share Index. On the other hand, the authors further opined that the relationship between Volatility and Market capitalization, volatility and value traded, volatility and All-Share Index is negative. Having established that the adopted market efficiency measures (Bid-Ask Spread, PBAS, Volume, and Volatility) are negatively impacted due to the existence of manipulation. It is expected that the aggregate market indicators share the resemblance of the adopted efficiency measures as a result of manipulation; the market indicators are distorted and their ability to effectively boost economic performance is weakened. Figure 4 shows the trend of market indicators between 2002 and 2016. 
There is a need to examine whether the distorted indicators can still improve economic performance in Nigeria. The tools adopted to determine the association between the level of Nigerian stock market efficiency and economic performance comprise; the Augmented Dickey-Fuller Unit Root Test (ADF), Johansen's co-integration test, Granger Causality Test and Error Correction Model. The various relevant tests conducted in this study are presented in tables as follows.

\subsubsection{Lag order selection criteria}

Estimating the lag length for time series variables is very essential in econometric exercise. The lag selection criteria were based on Hannan-Quinn information criterion, Schwarz information criterion and the Akaike information criterion. However, Liew (2004) opined that the most superior in the case of sample less than 60 observations is Akaike's information criterion. The reason for this is simple; the Akaike's information criterion minimizes the chance of underestimation when maximizing the chance of recovering the correct lag length. The result of lag order selection criteria is highlighted in Table 6.

As a rule of thumb, the minimum value of AIC indicates the optimum lag length. In the table above, the minimum value is -10.21080 and the optimum lag length is 6 . The optimum lag length is used while conducting the ADF unit root test.

\subsubsection{Augmented Dickey-Fuller Unit Root Test (ADF)}

Time series data often exhibit non-stationarity, to avoid the problem of spurious regression it becomes imperative to undertake a quantitative analysis to ascertain a stationary co-integrating association between all the variables. The result of the Augmented Dickey-Fuller test (ADF) is presented in Table 7.

The decision rule in the ADF test is to reject the null hypothesis if the value of ADF t-statistic (in absolute term) is more than the critical value at $5 \%$ level of significance. The results in Table 7 indicate that only All-Share Index (ASI) is stationary at level, whereas qgdp, CapR, toR and drR are stationary at first difference. However, $\mathrm{vtR}$ becomes stationary after second difference. It is worthy of note that running a regression model with varying orders of integration (like in Table 7) is also bound

Table 6 Lag order selection criteria

\begin{tabular}{llllrrr}
\hline Lag & Logl & LR & FPE & \multicolumn{1}{l}{ AIC } & \multicolumn{1}{l}{ SC } & HQ \\
\hline 0 & -144.37243 & NA & $2.70 \mathrm{e}-07$ & 1.900846 & 2.123898 & 1.986621 \\
1 & 225.2611 & 468.0432 & $4.03 e-11$ & -16.915514 & -15.354151 & -16.315089 \\
2 & 291.0284 & 99.27136 & $1.38 \mathrm{e}-11$ & -18.038807 & -15.130133 & -16.923732 \\
3 & 318.6510 & 35.4037 & $2.18 \mathrm{e}-1$ & -17.722681 & -13.484694 & -16.092956 \\
4 & 365.2198 & 49.20468 & $1.95 \mathrm{e}-11$ & -18.121500 & -12.545202 & -15.977125 \\
5 & 412.9795 & 39.64959 & $2.13 e-11$ & -18.565246 & -11.650654 & -15.906238 \\
6 & 492.5861 & 48.06437 & $1.08 \mathrm{e}-11$ & -110.21080 & -11.957875 & -17.037121 \\
\hline
\end{tabular}

Source: Author's E-view 9.5 Compilation

$L R$ sequential modified LR test statistic (each test at $5 \%$ level), FPE final prediction error, AIC Akaike information criterion, SC Schwarz information criterion, HQ Hannan-Quinn information criterion

*Lag order selected by the criterion 
Table 7 Augmented Dickey-Fuller Unit Root Test results (original model)

\begin{tabular}{lcc}
\hline Variables & t-statistics & $\begin{array}{l}\text { Order } \\
\text { of integration }\end{array}$ \\
\hline$\triangle$ qgdp ADF & -17.050863 & I(1) \\
Critical value 5\% level & -12.913549 & \\
$\triangle$ CapR ADF & -14.995001 & $\mathrm{I}(1)$ \\
Critical value 5\% level & -12.912631 & \\
$\triangle \triangle$ vtR ADF & -13.954056 & $\mathrm{I}(1)$ \\
Critical value 5\% level & -12.921175 & \\
ASI ADF & -13.246795 & $\mathrm{I}(0)$ \\
Critical value 5\% level & -12.914517 & $\mathrm{I}(1)$ \\
$\triangle$ toR ADF & -13.197402 & $\mathrm{I}(1)$ \\
Critical value 5\% level & -12.916566 & \\
$\triangle \mathrm{drR}$ ADF & -14.047625 & \\
Critical value 5\% level & -12.9516566 & \\
\hline
\end{tabular}

Source: Author's E-view 9.5 Compilation

Table 8 Augmented Dickey-Fuller Unit Root Test results (linearized model)

\begin{tabular}{llll}
\hline Variable & $\boldsymbol{t}$-static & Order of integration & $\boldsymbol{P}$-value \\
\hline$\triangle$ (lggdp) ADF & -13.50562 & $\mid(1)$ & 0.0114 \\
Critical value 5\% level & -12.915522 & & \\
$\triangle$ (lgCapR) ADF & -15.357871 & $\mid(1)$ & 0.0000 \\
Critical value 5\% level & -12.913549 & & \\
$\triangle$ (lgvtR) ADF & -14.13006 & $\mid(1)$ & 0.0019 \\
Critical value 5\% level & -12.913549 & & \\
$\triangle$ (lgASI) ADF & -16.52059 & $\mid(1)$ & \\
Critical value 5\% level & -12.912631 & & \\
$\triangle$ (lgtoR) ADF & -18.289225 & $\mid(1)$ & \\
Critical value 5\% level & -12.912631 & & \\
Critical value 5\% level & -12.915522 & &
\end{tabular}

Source: Author's E-view 9.5 Compilation

Table 9 Unrestricted co-integrated rank results (trace)

\begin{tabular}{llcll}
\hline $\begin{array}{l}\text { Hypothesized no. } \\
\text { of CE (s) }\end{array}$ & Eigenvalue & Trace statistic & $\begin{array}{l}\mathbf{0 . 0 5} \\
\text { Critical value }\end{array}$ & Prob** $^{* *}$ \\
\hline$r \leq 0$ & $0.668457^{*}$ & 145.7992 & 69.81889 & 0.0000 \\
$r \leq 1$ & $0.630122^{*}$ & 88.39126 & 47.85613 & 0.0000 \\
$r \leq 2$ & $0.294112^{*}$ & 36.67298 & 29.79707 & 0.0069 \\
$r \leq 3$ & $0.279642^{*}$ & 18.56145 & 15.49471 & 0.0167 \\
$r \leq 4$ & 0.028529 & 1.505093 & 3.841466 & 0.2199 \\
\hline
\end{tabular}

Source: Author's E-view 9.5 Compilation

Trace test indicates 4 co-integrating eqn(s) at the 0.05 level

${ }^{*}$ Rejection of the hypothesis at the 0.05 level

**Mackinnon-Haug-Michelis (1999) values

to produce spurious regression result. To avoid this, the regression equation in this study is linearized by taking the logarithms of all the variables in the model. The results of Augmented Dickey-Fuller Unit Root Test on the linearized equation are presented in Table 8. 
Table 10 Unrestricted co-integration rank test result (maximum eigenvalue)

\begin{tabular}{lcclc}
\hline \multicolumn{4}{l}{ Unrestricted co-integration rank test (maximum eigenvalue) } & \\
\hline $\begin{array}{l}\text { Hypothesized no. } \\
\text { of CE (s) }\end{array}$ & Eigenvalue & Max-eigen statistic & $\begin{array}{l}\mathbf{0 . 0 5} \\
\text { Critical value }\end{array}$ & Prob.** $^{*}$ \\
\hline$r \leq 0$ & $0.668457^{*}$ & 57.40794 & 33.87687 & 0.0000 \\
$r \leq 1$ & $0.630122^{*}$ & 51.71828 & 27.58434 & 0.0000 \\
$r \leq 2$ & 0.294112 & 18.11153 & 21.13162 & 0.1257 \\
$r \leq 3$ & 0.279642 & $17.15635^{*}$ & 14.26460 & 0.0176 \\
$r \leq 4$ & 0.028529 & 1.505093 & 3.841466 & 0.2199 \\
\hline
\end{tabular}

Source: Author's E-view 9.5 Compilation

Max-eigenvalue test indicates 3 co-integrating eqn(s) at the 0.05 level

${ }^{*}$ Rejection of the hypothesis at the 0.05 level

**Mackinnon-Haug-Michelis (1999) $P$-values

In Table 8, a comparison of the ADF t-statistic and with the corresponding critical values reflects that all the variables are integrated of order one $(\mathrm{I}(1))$ at $5 \%$ significant level.

\subsubsection{Co-integration test}

Tables 9 (trace statistic) and 10 (maximum eigenvalue) below present the unrestricted co-integration rank test results when capr, vtr, tor and drr are estimated on qgdp.

The null hypothesis in the table above highlights the number of co-integrated equations. As a rule of thumb, when the p-value is less than $5 \%$ level of confidence, there is strong evidence to reject the null hypothesis. The results reveal that null hypothesis is rejected at 'none', 'at most 1', 'at most 2', 'at most 3' due to the $p$ values falling below 0.05 level of significance. However, the null hypothesis is accepted at 'at most 4', suggesting that all the adopted variables are co-integrated. There is, therefore, strong evidence to conclude that there is a long-run relationship between stock market performance and economic growth in Nigeria.

The same rule of thumb applies to max-eigen statistic as trace statistic. Table 10 once again confirms the existence of two co-integrated equations at a 5\% significance level. Usually, the existence of co-integration among the adopted variables provides a justification to use Error Correction Model.

\subsubsection{Error Correction Model (ECM)}

Having established the existence of a long-run relationship between the adopted variables through co-integration analysis, short-run deviation of the variables cannot be ascertained from co-integration analysis, Error Correction Model addresses this problem. Error Correction Model examines the short-run dynamics as well as long-run adjustments. Table 11 presents the outcomes of the Error Correction Model.

Furthermore in Table 12, The ECM result shows that the error correction term $(\mathrm{u}$ $(-1))$ is negative $(-0.196727)$ after estimation) signifying a move back towards equilibrium and a good level of stability in the model. This speed of adjustments is a pointer that $19.67 \%$ of the preceding period's long-run disequilibrium in the Nigeria stock market is corrected within a quarter for capR, vtR, ASI, toR and drR. This result is theory consistent and reflects that for every disturbance in the system, capR, vtR, ASI, toR and 
Table 11 Error Correction Model (ECM) results

\begin{tabular}{|c|c|c|c|c|}
\hline Variable & Coefficient & Std. error & t-statistic & Prob \\
\hline C & 0.019139 & 0.010418 & 1.837133 & 0.0719 \\
\hline D(LGCAPR) & 0.186779 & 0.082024 & 2.277126 & 0.0269 \\
\hline D(LGVTR) & -10.034037 & 0.035213 & -10.966595 & 0.3382 \\
\hline $\mathrm{D}(\mathrm{LGASI})$ & -10.081220 & 0.078642 & -11.032773 & 0.3065 \\
\hline D(DLGTOR) & 0.028673 & 0.068030 & 0.421482 & 0.6751 \\
\hline $\mathrm{D}(\mathrm{LGDRR})$ & 0.005848 & 0.252750 & 0.023136 & 0.9816 \\
\hline $\mathrm{U}(-1)$ & -10.196727 & 0.088134 & -12.232133 & 0.0299 \\
\hline$R$-squared & 0.156335 & Mean dependent var & 0.025481 & \\
\hline Adjusted $R$-squared & 0.058989 & S.D. dependent var & 0.078253 & \\
\hline S.E of regression & 0.075910 & Akaike Info Criterion & -2.207551 & \\
\hline Sum squared resid & 0.299639 & Schwarz criterion & -1.961063 & \\
\hline Log likelihood & 72.12274 & Hannan-Quinn criterion & -2.111332 & \\
\hline F-Statistic & 1.605973 & Durbin-Watson & 2.307061 & \\
\hline Prob (F-Statistic) & 0.164189 & & & \\
\hline
\end{tabular}

Source: Author's E-view 9.5 Compilation

Table 12 Linearized non-stationary regression result

\begin{tabular}{lclcr}
\hline Variable & Coefficient & Std. error & $\boldsymbol{t}$-statistic & Prob. \\
\hline LGCAPR & 0.339842 & 0.074655 & 4.552199 & 0.0000 \\
LGVTR & -10.169378 & 0.014186 & -111.94021 & 0.0000 \\
LGASI & 0.256786 & 0.051614 & 4.975132 & 0.0000 \\
LGTOR & 0.471398 & 0.067581 & 6.975341 & 0.0000 \\
LGDRR & 1.085622 & 0.243378 & 4.460634 & 0.0000 \\
\hline R-squared & 0.908791 & Mean dependent var & 4.408295 & \\
Adjusted R-squared & 0.902158 & SD dependent var & 0.442443 & \\
SE of regression & 0.138395 & Akaike info criterion & -11.037757 & \\
Sum of squared resid & 1.053422 & Schwarz criterion & -10.863228 & \\
Log likelihood & 36.13270 & Hannan-Quinn criter. & -10.969489 & \\
Durbin-Watson stat & 1.086658 & & & \\
\hline
\end{tabular}

Source: Author's E-view 9.5 Compilation

drR jointly possess a significant force to return the model to equilibrium. Usually, when the error correction term is significant and negative (as shown in Table 11) it indicates the existence of a long-run equilibrium relationship between the dependent variable and the explanatory variable. In this case, there exists a long-term relationship between stock market efficiency and economic growth.

In the results, the coefficient of determination ( $R$-square) is 0.156335 . This shows that the adopted stock market efficiency measures are capable of explaining $15.634 \%$ variation in economic growth in Nigeria. Although this might be considered low, it is important to say that there are so many variables that impact on GDP other than stock market performance. In Nigeria for instance, factors such as the volume of export, Government debt, foreign aid, human capital/life expectancy, technology, political instability, technology, and foreign direct investment are among the major predictors of GDP. Since it is not expected that the adopted model should include all the relevant predictors, it is also 
unexpected that only stock market performance would be a major contributor (explaining a huge variation in GDP). The Durbin-Watson (2.307061) indicates that there exists approximately no autocorrelation in the sample and the results are therefore reliable.

This study finds that value traded ratio has an insignificant negative impact $(-0.034037)$ on GDP at $5 \%$ level of significance. This means a $1 \%$ increase in value traded ratio leads to a $3.4 \%$ reduction in GDP. This suggests that an increase in value traded ratio (a measure of liquidity) might result from manipulation since the manipulation period is characterized with inflated liquidity. As evidenced earlier, the coefficient of the volume is a small negative figure $(-0.00003)$ as shown in Table 5 . The negative coefficient of volume reveals an inverse association between total amount traded and spread. The result of regression Eqs. 8 provides good evidence to suggest that manipulation widens relative spreads and causes a contraction of trading volume at the postmanipulation period. Having established that the trading volume in Nigeria is distorted as a result of manipulation. The negative impact of value traded on GDP is a reflection of what happens when we examine the impact of a distorted variable on growth indicator. Value traded is distorted due to manipulation and its ability to cause growth is weakened. Similar to the value traded ratio, the All-Share Index has an insignificant negative impact $(-0.081220)$ on GDP at $5 \%$ level of significance. For every $1 \%$ increase in the AllShare Index, GDP declines by $8 \%$.

In the regression results, coefficient of market capitalization ratio is positive (0.186779) and significant $(p$ value $=0.0269)$ at $5 \%$ level of significance, this shows that for every $1 \%$ increase in market capitalization, GDP is increased by $18.68 \%$. This empirical result is insightful, it suggests that despite being distorted, market capitalization still can strengthen the chances of corporations to raise capital. When this happens, corporations' investment expenditures and production capacity are expanded which ultimately are likely to impact on economic growth. It must be noted that, since volatility is found to widen as a result of manipulation (as evidenced earlier in this study), genuine investors are often forced out of the market at the post-manipulation period. As a result, market capitalization is significantly impaired and its expected positive influence on economic growth is shortened. It is on this basis; we can argue that whatsoever impacts market capitalization negatively has the potential to harm economic performance. Jovanovic and Rousseau (2000) find that the existence of a liquid and highly capitalized stock market promotes economic growth. The implication of this would mean that the existence of manipulation in Nigeria caused the stock market to be less capitalized at the postmanipulation period resulting in lower risk diversification and higher cost of capital.

Similarly, trade openness ratio has an insignificant positive (0.028673) impact on GDP at $5 \%$ significant level. A $1 \%$ increase in trade openness results in $2.87 \%$ increase in GDP. This study finds that, despite the positive contribution of trade openness to economic growth, Nigeria is yet to develop appropriate policies to improve export volume, thereby increasing the contribution of international trade to economic growth. The recent policy of restricting transfers on international transactions is not only anti-investment but constitutes a typical hindrance to smooth inflow of foreign investment which could have helped to revive the stock market and brought about increased access to capital for corporations. Since stock market integrity is eroded as a result of manipulation, potential foreign investors exercise great caution before engaging in investment activities. 
Investment rate (domestic and foreign inflow) could have been accelerated and a lot of foreign investment attracted in the absence of manipulation. Over the years, domestic investment has been on a decline, volume of export is dwindling, trade openness is affected and the significant contribution of trade openness to GDP has been diluted.

Moreover, the estimates reveal an insignificant positive $0.5848 \%$ effect of discount rate on GDP at $5 \%$ level of significance. For every $1 \%$ increase in the discount rate, GDP is increased by $0.585 \%$. As noted earlier in this study, the manipulation period is characterized with high liquidity which drastically declines at the post-manipulation period. Often time, government intervention (via discount rate) is needed to revive the stock market and bring about financial development. Hence, the liquidity shocks in the equity market created by manipulation could be adjusted through the discount rate. Although the contribution of the discount rate is found to be insignificant, it influences the ability of banks to supply funds for possible investment in the financial market to cushion the aftermath of manipulation. The finding in this study that stock market efficiency (proxy by market capitalization ratio) improves economic growth is consistent Levine and Zervos (1996), Agarwal and Mohtadi (2004), Choong et al. (2003), Minier (2003), and Bahadur and Neupane (2007); their studies reported a significant positive impact of stock market development on economic growth.

\subsubsection{Granger Causality Test}

It is important to ascertain the direction of causality between stock market efficiency and economic performance. This study adopts the pairwise Granger causality approach to establish whether each of the explanatory variables can be used to predict the dependent variable. It is required that the variables of interest are stationary before running the Granger Causality Test, we, therefore, use the stationary and linearized variables shown in Table 8. The results of the Granger Causality Test are presented in Table 13.

The results in Table 13 report that market capitalization ratio (a proxy for stock market efficiency) does not Granger Cause economic growth and vice versa at $5 \%$ significant level (the $p$ values $0.688,0.5646>0.05$ ). Similarly, value traded ratio (vtR) does not Granger Cause economic growth and vice versa at $5 \%$ significant level ( $p$ values 0.9945 , $0.3344>0.05)$. However, a uni-directional causality is found between All-Share Index ( $p$

Table 13 Granger Causality Test results

\begin{tabular}{lccc}
\hline Null hypothesis: & Obs. & F-statistic & Prob. \\
\hline DLGCAPR does not Granger Cause DLGGDP & 53 & 1.11885 & 0.3688 \\
DLGGDP does not Granger Cause DLGCAPR & & 0.81512 & 0.5646 \\
DLGVTR does not Granger Cause DLGGDP & 53 & 0.11222 & 0.9945 \\
DLGGDP does not Granger Cause DLGVTR & & 1.18379 & 0.3344 \\
DLGASI does not Granger Cause DLGGDP & 53 & 2.69881 & 0.0270 \\
DLGGDP does not Granger Cause DLGASI & & 1.35628 & 0.2557 \\
DLGTOR does not Granger Cause DLGGDP & 53 & 2.97993 & 0.0168 \\
DLGGDP does not Granger Cause DLGTOR & & 1.00938 & 0.4329 \\
DLGDRR does not Granger Cause DLGGDP & 53 & 2.89442 & 0.0194 \\
DLGGDP does not Granger Cause DLGDRR & & 1.08696 & 0.3867 \\
\hline
\end{tabular}

Source: Author's E-view 9.5 Compilation 
value $0.0270<0.05)$ and economic growth, Trade openness ratio ( $p$ value $0.0168<0.05)$ and economic growth, Discount rate $(p$ value $0.0194<0.05)$ and economic growth.

\section{Conclusion}

This study empirically investigates the impact of stock market manipulation on Nigerian economic performance, and to examine the reactions of market efficiency measures to manipulative trading. Similarly, the second objective is to examine whether manipulation distorts the market during and after the manipulation period. To achieve the first and second objectives, certain market efficiency measures such as Volume, volatility, bid-ask spread and the proportional bid-ask spread, were carefully selected as they are found to directly impact market efficiency. The efficiency measures have been empirically reviewed, by researchers such as Aggarwal and Wu (2003) and Gerace et al. (2014) and reported to influence the trend of stock market indicators. The idea is to establish that market indicators are distorted by examining the reactions of Market capitalization, Total value traded and All-Share Index (market indicators) to variations in the market efficiency measures as a result of manipulation. The researcher analysed intra-day data of market efficiency measures using "event study" methodology, Univariate analysis, and regression analysis.

Also, since the impact of manipulation on economic growth is not direct, this study first established that manipulation distorts the adopted efficiency measures. We should note that the selected efficiency measures directly impact on the identified market indicators. The researcher then concludes that whatever distorts the efficiency measures has the potential to distort the selected market indicators. The researcher analysed quarterly average data of market indicators and economic growth indicator (proxy by GDP) using the Error Correction Model from E-views software to examine the impact of distorted market indicators on economic growth.

This study finds that bid-ask spread (a measure of efficiency and information asymmetry) widens in response to manipulation, liquidity rises during manipulation and significantly shrinks at the post-manipulation period, volatility was also noticed to increase considerably. This evidence presents that a great level of inefficiency was unveiled in the Nigerian stock market as a result of manipulation. The first and second objectives have been achieved in that stock market manipulation was found to distort the market and created a negative impact. This result correctly replicates the assumption of market microstructure theory. Despite the empirical evidence that the market indicators were distorted, market capitalization was found to positively impact economic growth. This is consistent with the findings of Adenuga (2010); Ojo and Adeusi (2012) and Atoyebi et al. (2013). However, value traded ratio and All-Share Index were found to harm economic growth as consistent with Kolapo and Adaramola (2012); Nwaolisa et al. (2013) and Salihi et al. (2015). The third objective has been achieved in that the trend of market indicators at the post-manipulation period impacted economic performance negatively.

Having demonstrated that there is a positive relationship between stock market efficiency and economic growth in Nigeria (as evidenced by the significant positive impact of market capitalization on GDP), necessary measures should put in place to restore the confidence of investors and market participants. Every form of abuse and 
sharp practices that amount to manipulation should be eradicated. Relevant institutional factors such as equity and fair-trading policies, rule of law should be established. The security and Exchange Commission should design a responsive legal framework to ensure early detection and prosecution of manipulation. Lastly, to avoid policy somersault, that is often witnessed when there is a change of political offices in Nigeria, the ongoing reforms should be sustained to restore market integrity and make the Nigerian Stock Exchange live to its full potentials.

The study of Onakoya (2013) is similar to this research, although his study only applies to the effects of stock market volatility on economic growth. Meanwhile, Onakoya's study is dated and his findings might have changed in light of new information. Other studies that considered actual manipulation cases in Nigeria were not found. By illustrating the negative influence of NSE actual manipulation cases on economic performance, this research will be of major importance to; the Nigerian government, the Central Bank of Nigeria and the Securities and Exchange Commission to actively design legal responses to deter and prosecute market manipulation; the institutional operators of the NSE and subsequent researchers to whom this research may be of immense value; as well as the investors who are usually the main target of an average manipulator. Importantly, regulators should be aware of the unlawful trading practices, a wide range of methods to identify manipulation techniques and effective ways to enforce actions against it. By exposing the economic consequences of stock manipulation, this paper seeks to prompt regulators towards ensuring effective systems to address manipulative trading.

Acknowledgements

Author gratitude is extended to the prospective editor(s) and reviewers that will/have spared time to guide toward a successful publication.

\section{Authors' contributions}

The first authors BA was responsible for conceptual construction of the study's idea and empirical modelling while FFA conducted econometrics section. Finally, FVB handled the proofreading of the entire manuscript.

Funding

I hereby declare that there is no form of funding received for this study.

Availability of data and materials

The data for this present study are sourced from the Nigeria Stock Exchange Database includes opening and closing prices, the daily average of high and low prices, volume of trade, and average ask and bid prices

\section{Competing interests}

I wish to disclose here that there are no potential conflicts of interest at any level of this study.

\section{Author details}

${ }^{1}$ Department of Accounting, Economics and Finance, Bournemouth University, Poole, UK. ${ }^{2}$ Department of Logistics and Transportation, Istanbul Gelisim University, Istanbul, Turkey. ${ }^{3}$ Department of Accounting, Analysis and Audit, School of Economics and Management, South Ural State University, 76, Lenin Aven, Chelyabinsk 454080, Russia.

Received: 11 January 2020 Revised: 22 May 2020 Accepted: 29 July 2020

Published online: 29 August 2020

\section{References}

Adamu JA, Sanni I (2005) Stock market development and Nigerian economic growth. J Econ Allied Fields 2(2):116-132 Adenuga AO (2010) Stock market development indicators and economic growth in Nigeria (1990-2009), Empirical investigations. Central Bank Nigeria Econ Fin Rev 48(1):33-70

Agarwal S, Mohtadi H (2004) Financial markets and the financing choice of firms: evidence from developing countries. Glob Fin J 15(1):57-70

Aggarwal RK, Wu G (2003) Stock market manipulation-theory and evidence. In: Paper presented at the AFA 2004 San Diego Meetings. Accessed 24 Nov 2016

Alajekwu U, Achugbu A (2012) The role of stock market development on economic growth in Nigeria: a time series analysis. Afr Res Rev 6(1):51-70 
Aliyu A (2014) Impact of corporate crime on developing capital markets: a case study of Nigeria. 8(2):181-196. http://infin itypress.info/index.php/jsss/article/download/791/364. Accessed 2 Feb 2017

Anigbogu U, Nduka E (2014) Stock market performance and economic growth: evidence from Nigeria employing vector error correction model framework. Econ Fin Lett 1(4):90-103

Apati S (2012) Policy on the run: currency re-denomination and bank manipulation. The Nigerian Banking Sector Reforms. Springer, Berlin, pp 71-103

Arzarmi T, Lazar D, Jeyapaul J (2005) Is the Indian Stock Market A Casino? J Bus Econ Res 3(4):63-72

Asongu SA (2012) Government quality determinants of stock market performance in African Countries. J Afr Bus 13(3):183-199. https://doi.org/10.1080/15228916.2012.727744

Asongu SA (2013) African stock market performance dynamics: a multidimensional convergence assessment. J Afr Bus 14(3):186-201. https://doi.org/10.1080/15228916.2013.844043

Asongu S, Nwachukwu JC (2016) Political regimes and stock market performance in Africa. In: MPRA Paper

Asteriou D, Spanos K (2019) The relationship between financial development and economic growth during the recent crisis: evidence from the EU. Fin Res Lett 28:238-245

Atoyebi KO, Ademola IB, Kadiri IK, Adekunjo OF, Ogundeji OM (2013) Capital market and economic growth in Nigeria an empirical analysis. J Hum Soc Sci 6(6):60-68

Bahadur S, Neupane S (2007) Stock market and economic development: a causality test. J Nep Bus Stud 3(1):36

Ball R, Brown P (1968) An empirical evaluation of accounting income numbers. J Accoun Res 6(2):159

Batuo M, Mlambo K, Asongu S (2018) Linkages between financial development, financial instability, financial liberalisation and economic growth in Africa. Res Int Bus Fin 45:168-179. https://doi.org/10.1016/j.ribaf.2017.07.148

Belcaid K, El Ghini A (2019) Spillover Effects among European, the US and Moroccan Stock Markets before and after the Global Financial Crisis. J Afr Bus 20(4):525-548. https://doi.org/10.1080/15228916.2019.1582266

Bencivenga V, Smith B (1991) Financial intermediation and endogenous growth. Rev Econ Stud 58(2):195

Boamah NA (2017) The price of risk on the African Frontier Stock Markets. J Afr Bus 18(2):238-256. https://doi. org/10.1080/15228916.2017.1282292

Boubakari A, Jin D (2010) The role of stock market development in economic growth: evidence from some Euronext Countries. Int J Fin Res 1(1):14-20

Brown ED, Nyeche EW (2016) The Imperative of Stock Market on Economic Growth in Nigeria: "The Endogenous Growth Model". Bus Econ J 7:01

Cheng F, Gul F (2010) Stock markets, banks and economic growth: some evidence on the role of stock price informativeness. In: SSRN Electronic Journal

Choong C, Yusop Z, Law S, Khim-Sen Liew V (2003) Financial development and economic growth in Malaysia: the stock market perspective. Ideas.repec.org. https://ideas.repec.org/p/wpa/wuwpma/0307010.html. Accessed 12 Mar 2017

Cournède B, Denk O (2015) Finance and economic growth in OECD and G20 countries. In: OECD Economic Department Working Papers 1223, OECD Publishing

Easley D, O'Hara M (1987) Price, trade size, and information in securities markets. J Financ Econ 19(1):69-90

Fischel D, Carlton D (1982) The Regulation of Insider Trading. Chicagounbound.uchicago.edu. http://chicagounbound. uchicago.edu/cgi/viewcontent.cgi?article=2424\&context=journal_articles. Accessed $30 \mathrm{Mar} 2017$

Frank M, Goyal V (2007) Trade-off and pecking order theories of debt. In: SSRN Electronic Journal

Gao L, Kling G (2006) Regulatory changes and market liquidity in Chinese stock markets. Emerg Markets Rev 7(2):162-175

Gerace D, Chew C, Whittaker C, Mazzola P (2014) Stock market manipulation on the Hong Kong stock exchange. Aust Account Bus Fin J 8(4):105-140

Gujarati DN (1995) Basic Econometrics, 3rd edn. McGraw-Hill, New York. ISBN 0-07-025214-9

Gursoy CT, Muslumov A (1999) Stock Markets and Economic Growth: Causality Test. MBA Thesis Submitted to the Institute of Social Sciences, Istanbul Technical University Turkey, pp. 124-131

Huang HCR, Fang W, Miller SM (2014) Does financial development volatility affect industrial growth volatility? Int Rev Econ Fin 29(1):307-320

Jovanovic B, Rousseau PL (2000) Technology and the stock market: 1885-1998. In: Vanderbilt University Department of Economics Working Papers 0042, Vanderbilt University Department of Economics

King R, Levine R (1993) Finance and growth: Schumpeter might be right. Q J Econ 108(3):717-737

Kirikkaleli D (2016) Interlinkage between economic, financial, and political risks in the balkan countries: evidence from a panel cointegration. Eastern Eur Econ 54(3):208-227. https://doi.org/10.1080/00128775.2016.1168704

Kirikkaleli D (2019) Time-frequency dependency of financial risk and economic risk: evidence from Greece. J Econ Struct. https://doi.org/10.1186/s40008-019-0173-z

Kirikkaleli D (2020) The effect of domestic and foreign risks on an emerging stock market: a time series analysis. North Am J Econ Fin 51:100876. https://doi.org/10.1016/j.najef.2018.11.005

Kirikkaleli D, Gokmenoglu KK (2019) Sovereign credit risk and economic risk in Turkey: empirical evidence from a wavelet coherence approach. Borsa Istanbul Rev. https://doi.org/10.1016/j.bir.2019.06.003

Kolapo FT, Adaramola AO (2012) The impact of the Nigerian capital market on economic growth (1990-2010). Int J Dev Soc 1(1):11-19

Krinsky I, Lee J (1996) Earnings announcements and the components of the bid-ask spread. J Fin 51 (4):1523-1535

Leas PL (1974) The measure of damages in rule 10b-5 cases involving actively traded securities. Stanford Law Rev 26(2):371-398. https://doi.org/10.2307/1227792

Levine R, Zervos S (1996) Stock market development and long-run growth. World Bank Econ Rev 10(2):323-339

Liew V (2004) Which lag length selection criteria should we employ? Econ Bull 3(33):1-9

Lin PC, Huang HC (2012) Banking industry volatility and growth. J Macroecon 34(4):1007-1019

Madsen JB, Ang JB (2016) Finance-led growth in the OECD since the nineteenth century: how does financial development transmit to growth? Rev Econ Stat 98(3):552-572

Martin F (2013) Government policy in monetary economies. Int Econ Rev 54(1):185-217

Minier J (2003) Are small stock markets different? J Monetary Econ 50(7):1593-1602 
Numapau E (2018) Adaptive market hypothesis: evidence from the ghanaian stock market. J Afr Bus 19(2):195-209. https $: / /$ doi.org/10.1080/15228916.2018.1392838

Nurudeen A (2009) Does stock market development raise economic growth? Evidence from Nigeria. The review of Finance and Banking, Nigeria

Nwaolisa E, Kasie E, Egbunike C (2013) The impact of capital market on the growth of the Nigerian economy under democratic rule. Arabian J Bus Manag Rev 3(2):53-62

Nyasha S, Odhiambo NM (2017) Banks, stock market development and economic growth in Kenya: an empirical investigation. J Afr Bus 18(1):1-23. https://doi.org/10.1080/15228916.2016.1216232

Nyong MO (1997) Capital market development and long-run economic growth: theory evidence and analysis. In: First Bank Review, December 1997, pp. 13-38

Ojo OM, Adeusi SO (2012) Impact of capital market reforms in economic growth: the Nigerian experience. Aust J Bus Manag Res 2:2

Onakoya A (2013) Stock market volatility and economic growth in Nigeria (1980-2010). Int Rev Manag Bus Res 2:1

Osinubi T, Amaghionyeodiwe L (2003) Stock market development and long-run growth in Nigeria. J Afr Bus 4(3):103-129

Salihi AA, Ibrahim FB, Muhammad S, Ahmad T (2015) An assessment of Nigerian stock exchange market development to economic growth. Am Int J Soc Sci 4(2325-4149):51-58

Thel S (1993) \$850,000 in six minutes-the mechanics of securities manipulation. Cornell Law Rev 79:219.

Wei SJ (2014) Financial systems and economic outcomes: a comparative perspective. Glob Econ Rev 43(4):315-318

Yeh C, Huang H, Lin P (2013) Financial structure on growth and volatility. Econ Model 35(5):391-400

Zhang L, Zhang S, Tao N (2016) Financial system risk tolerance capacity and economic growth: evidence from a crosscountry analysis. Glob Econ Rev 45(2):97-115

\section{Publisher's Note}

Springer Nature remains neutral with regard to jurisdictional claims in published maps and institutional affiliations.

\section{Submit your manuscript to a SpringerOpen ${ }^{\odot}$ journal and benefit from:}

- Convenient online submission

- Rigorous peer review

- Open access: articles freely available online

- High visibility within the field

Retaining the copyright to your article

Submit your next manuscript at $\gg$ springeropen.com 